\title{
COMMENTS
}

\section{Apportionment Between Partmakers and Assemblers in Strict Liability}

$A$ makes steering mechanisms for sale to automobile manufacturers, including $B$, which in turn assemble and sell automobiles to the public. $B$ sells a car to $C$, who is subsequently injured when the car veers off a highway. $C$ sues for compensatory damages on a theory of strict products liability, ${ }^{1}$ alleging that defects in the steering mechanism proximately caused the accident. He prevails at trial and is awarded $\$ 100,000$. In most jurisdictions either $A, B$, or both can be held liable for C's injuries. ${ }^{2}$

Courts traditionally have used theories of indemnification, ${ }^{3}$

1 Restatement (SECOND) of ToRts $\S 402 A$ (1) (1965) [hereinafter cited as Restatement (SECOND)] provides:

One who sells any product in a defective condition unreasonably dangerous to the user or consumer or to his property is subject to liability for physical harm thereby caused to the ultimate user or consumer, or to his property, if

(a) the seller is engaged in the business of selling such a product, and

(b) it is expected to and does reach the user or consumer without substantial change in the condition in which it is sold.

Thirty-seven jurisdictions follow section 402A(1). 1 Prod. LiAB. ReP. (CCH) \& 4016 (July 1980).

${ }^{2}$ On assembler liability, see, e.g., LeBouef v. Goodyear Tire \& Rubber Co., 623 F.2d 985 (5th Cir. 1980) (applying Louisiana law); Vandermark v. Ford Motor Co., 61 Cal. 2d 256, 391 P.2d 168, 37 Cal. Rptr. 896 (1964); Bradford v. Bendix-Westinghouse Automotive Air Brake Co., 33 Colo. App. 99, 517 P.2d 406 (1973); Hawkeye-Sec. Ins. Co. v. Ford Motor Co., 174 N.W.2d 672 (Iowa 1970); Goldberg v. Kollsman Instrument Corp., 12 N.Y.2d 432, 191 N.E.2d 81, 240 N.Y.S.2d 592 (1963). On component manufacturer liability, see, e.g., E.I. du Pont de Nemours \& Co. v. McCain, 414 F.2d 369 (5th Cir. 1969) (applying Texas law); Suvada v. White Motor Co., 32 Ill. 2d 612, 210 N.E.2d 182 (1965); Clark v. Bendix Corp., 42 A.D.2d 727, 345 N.Y.S.2d 662 (1973); Burbage v. Boiler Eng'g \& Supply Co., 433 Pa. 319, 249 A.2d 563 (1969).

${ }^{3}$ Where $C$ sues only $A$, the indemnification rule would allow $A$ to recover fully from $B$, but only if $A$ is the less culpable of the two. Compare Tromza v. Tecumseh Prods. Co., 378 F.2d 601 (3d Cir. 1967); Feinstein v. Edward Livingston \& Sons, 457 S.W.2d 789 (Mo. 1970); and Burbage v. Boiler Eng'g \& Supply Co., $433 \mathrm{~Pa} .319,249$ A.2d 563 (1969) (indemnity allowed) with Topel v. Porter, 95 Ill. App. 2d 315, 237 N.E.2d 711 (1968); Reid v. Royal Ins. Co., 80 Nev. 137, 390 P.2d 45 (1964); and United Tractor, Inc. v. Chrysler Corp., 563 S.W.2d 


\section{pro-rata contribution, ${ }^{4}$ and no contribution ${ }^{5}$ to govern apportion- ment among joint tortfeasors. ${ }^{8}$ Courts have begun to employ prin- ciples of comparative negligence ${ }^{7}$ in allocating liability between plaintiffs and defendants in strict liability actions, ${ }^{8}$ however, and}

850 (Tex. Civ. App. 1978) (indemnity denied). The ambiguities of this approach have been criticized. See Dole v. Dow Chem. Co., 30 N.Y.2d 143, 147-50, 282 N.E.2d 288, 291-93, 331 N.Y.S.2d 382, 386-89 (1972). See generally Comment, The Allocation of Loss Among Joint Tortfeasors, 41 S. CAL. L. REv. 728, 737-41 (1968).

- Pro-rata contribution would divide liability evenly between $A$ and $B$ regardless of their relative culpability and regardless of $C$ 's choice of defendant. See Rock v. Reed-Prentice Div. of Package Mach. Co., 39 N.Y.2d 34, 38-39, 346 N.E.2d 520, 522, 382 N.Y.S.2d 720, 721-22 (1976); Uniform Contribution Among Tortreasors ACt $\$$ 1, 2, 12 U.L.A. 63, 87 (1955); Leflar, Contribution and Indemnity Between Tortfeasors, 81 U. PA. L. REv. 130 (1932); Comment, Another Look at Strict Liability: The Effect on Contribution Among Tortfeasors, 79 Dick. L. REv. 125, 126-34 (1974); Note, Adjusting Losses Among Joint Tortfeasors in Vehicular Collision Cases, 68 Yale L.J. 964 (1959).

s Under the no-contribution rule, $C$ 's choice of defendant would be undisturbed, for the liable tortfeasor would be prevented from recovering any portion of the judgment against him from the other. See, e.g., Skaja v. Andrews Hotel Co., 281 Minn. 417, 161 N.W.2d 657 (1968); Goldman v. Mitchell-Fletcher Co., 292 Pa. 354, 141 A. 231 (1928). See also Comment, Relative Contribution Among Tortfeasors: Time for Judicial Change of the Washington Rule?, 11 Gonz. L. Rev. 179 (1975); Note, Contribution and Indemnity Among Tortfeasors, 31 MoNT. L. REv. 69 (1969).

- The apportionment issue can arise either where the plaintiff joins both tortfeasors, see LeBouef v. Goodyear Tire \& Rubber Co., 623 F.2d 985 (5th Cir. 1980); Favors v. Firestone Tire \& Rubber Co., 309 So. 2d 69 (Fla. Dist. Ct. App. 1975); Suvada v. White Motor Co., 32 Ill. 2d 612, 210 N.E.2d 182 (1965), or where the plaintiff sues only one tortfeasor, who subsequently seeks indemnification or contribution from the other, see Thomas v. Kaiser Agricultural Chems., 81 IIl. 2d 206, 407 N.E.2d 32 (1980); Liberty Mut. Ins. Co. v. Williams Mach. \& Tool Co., 62 Ill. 2d 77, 338 N.E.2d 857 (1975); Dole v. Dow Chem. Co., 30 N.Y.2d 143, 282 N.E.2d 288, 331 N.Y.S.2d 382 (1972).

7 There are two forms of comparative negligence: "pure," where the plaintiff's recovery is reduced by the percentage of his negligence, and "modified," where the plaintiff is barred from recovery if his own negligence equals or exceeds $50 \%$. See V. Schwartz, Comparativi Negligence 268-71 (1974). When applied to apportionment of damages among joint tortfeasors, "pure" comparative negligence principles lead to each tortfeasor paying according to his percentage of fault. See, e.g., Packard v. Whitten, 274 A.2d 169 (Me. 1971); Bielski v. Schulze, 16 Wis. $2 d$ 1, 114 N.W.2d 105 (1962). For example, in a case where damages of $\$ 100,000$ are awarded, and $A$ is $40 \%$ culpable and $B$ is $60 \%$ culpable, $A$ pays $C \$ 40,000$ and $B$ pays $C \$ 60,000$. Modified comparative negligence produces the same results as pure comparative negligence except for the case in which $C$ 's culpability exceeds the total of $A$ 's and $B$ 's culpability. Thus, if $C$ is $60 \%$ culpable and $A$ and $B$ are each $20 \%$ culpable, $C$ recovers nothing. Under pure comparative negligence $C$ recovers $\$ 20,000$ from $A$ and $\$ 20,000$ from $B$. See Walton v. Tull, 234 Ark. 882, 891-95, 356 S.W.2d 20, 25-27 (1962).

- See, e.g., Butaud v. Suburban Marine \& Sporting Goods, Inc., 555 P.2d 42 (Alaska 1976); Daly v. General Motors Corp., 20 Cal. 3d 725, 734-35, 575 P.2d 1162, 1167, 144 Cal. Rptr. 380, 385 (1978); West v. Caterpillar Tractor Co., 336 So. 2d 80 (Fla. 1970); Busch v. Busch Constr., Inc., 262 N.W.2d 377, 393-94 (Minn. 1977); Thibault v. Sears, Roebuck \& Co., 118 N.H. 802, 395 A.2d 843 (1978); Baccelleri v. Hyster Co., 287 Or. 3, 597 P.2d 351 (1979).

Some courts and commentators have opposed the infusion of comparative negligence 
we may now expect them to use these principles in apportioning strict liability among tortfeasors. ${ }^{9}$ This approach, referred to in this comment as comparative apportionment, ${ }^{10}$ would divide liabil-

principles into strict liability actions. See Kinard v. Coats Co., 553 P.2d 835, 837 (Colo. Ct. App. 1976); Kirkland v. General Motors Corp., 521 P.2d 1353, 1367 (Okla. 1974); General Motors Corp. v. Simmons, 558 S.W.2d 855, 862-63 (Tex. 1977); Levine, Strict Products Liability and Comparative Negligence: The Collision of Fault and No-Fault, 14 SAN DiEgo L. REv. 337 (1977); Comment, Comparative Fault and Products Liability: Are They Compatible?, 5 PePperdine L. Rev. 501 (1978). These arguments have been characterized as appeals not to "mix oil and water," see Feinberg, The Applicability of a Comparative Negligence Defense in a Strict Products Liability Suit Based on Section 402A of the Restatement of Torts $2 d$ (Can Oil and Water Mix?), 42 INs. Couns. J. 39 (1975), or to "compare apples and oranges," see Safeway Stores, Inc. v. Nest-Kart, 21 Cal. 3d 322, 331, 579 P.2d 441, 445, 146 Cal. Rptr. 550, 554 (1978); Wade, Products Liability and Plaintiff's Fault-The Uniform Comparative Fault Act, 29 Mercer L. Rev. 373, 376 (1978). See also Comment, supra, at 515. Compare the approach taken in Wisconsin, where the supreme court noted that strict liability is equivalent to negligence per se, thereby enabling the state's comparative negligence statute to be applied to strict liability actions. Dippel v. Sciano, 37 Wis. $2 d 443,461-$ 62, 155 N.W.2d 55, 64-65 (1967) (dictum).

- See, e.g., City of Franklin v. Badger Ford Truck Sales, Inc., 58 Wis. 2d 641, 207 N.W.2d 866 (1973). See also Model UnIform Products Liability Act § 111 (U.S. Dept. of Commerce 1979) (requiring apportionment according to percentage of fault) [hereinafter cited as MUPLA], reprinted in 44 Fed. Reg. 62,714, 62,734-35 (1979); Uniform ComparaTIVE FAULT ACT \$ 4, 12 U.L.A. 40, 41 (Supp. 1981) (providing for "pure" contribution among tortfeasors). Cf. Safeway Stores, Inc. v. Nest-Kart, 21 Cal. 3d 322, 579 P.2d 441, 146 Cal. Rptr. 550 (1978) (comparative apportionment between a strictly liable defendant and a negligent defendant).

${ }^{10}$ Some courts and writers have tried to finesse the perceived conflict between comparative negligence principles and strict liability by labeling the doctrine "comparative fault." See Horn v. General Motors Corp., 17 Cal. 3d 359, 551 P.2d 398, 131 Cal. Rptr. 78 (1976) (Clark, J., dissenting); Kroll, Comparative Fault: A New Generation in Products Liability, 1977 INs. L.J. 492; Twerski, From Defect to Cause to Comparative Fault-Rethinking Some Product Liability Concepts, 60 MARQ. L. REv. 297 (1977) [hereinafter cited as Rethinking].

Some maintain that comparative fault cannot be applied to strict liability because strict liability is a no-fault doctrine. See, e.g., Levine, supra note 8; Comment, supra note 8 . There is much support, however, for the view that strict liability actually does involve fault. See, e.g., Caterpillar Tractor Co. v. Beck, 593 P.2d 871, 889 (Alaska 1979) ("The production and marketing of a defective product is tantamount to 'fault' in the sense that we will impose legal responsibility for it."); Thibault v. Sears, Roebuck \& Co., 118 N.H. 802, 395 A.2d 843 (1978); Twerski, The Use and Abuse of Comparative Negligence in Products Liability, 10 IND. L. REv. 797, 819-30 (1977); Wade, supra note 8, at 376-77 (1978). See also Christopherson v. Hyster Co., 58 Ill. App. 3d 791, 374 N.E.2d 858 (1978).

Others have labeled the concept "comparative causation." See Pan-Alaska Fisheries, Inc. v. Marine Constr. \& Design Co., 565 F.2d 1129, 1139 (9th Cir. 1977); Sun Valley Airlines, Inc. v. Avco-Lycoming Corp., 411 F. Supp. 598, 603 (D. Idaho 1976); Twerski, The Many Faces of Misuse: An Inquiry Into the Emerging Doctrine of Comparative Causation, 29 Mercer L. Rev. 403 (1978); Comment, Comparative Causation, Indemnity, and the Allocation of Losses Between Joint Tortfeasors in Products Liability Cases, 10 ST. Mary's L.J. 587 (1979) [hereinafter cited as St. Mary's Comment]; Comment, Comparative Causation: A Legislative Proposal for the Equitable Allocation of Loss Between Strictly Liable 
ity between component manufacturers and final-product assemblers according to their relative percentages of culpability. Thus, if $A$ were held to be $40 \%$ culpable and $B$ to be $60 \%$ culpable, $A$ would pay $C \$ 40,000$ and $B$ would pay $C \$ 60,000$.

This comment argues that the comparative apportionment approach is doubly flawed. Because the question of apportionment is typically left to the jury, ${ }^{11}$ divisions of liability tend to be arbitrary and standardless. ${ }^{12}$ Moreover, even if principled guidelines for determining percentages of culpability could be enforced, apportionment frequently undermines the policies behind strict liability and fails to provide the correct behavioral incentives to component manufacturers and final-product assemblers. The comment argues instead that the "cheapest cost avoider" should bear full liability. Under this approach, the factfinder should simply ask who can more easily detect and correct the defect. The comment then argues that where detection and correction efficiencies are divided between component manufacturers and product assemblers, a "duty-to-warn" analysis should be employed. Under this approach, the party with the lowest detection costs would bear full liability, but could shift this liability to the party with the lowest correction costs if it provided a full warning of the detected dangers. Finally, the comment examines the case law and demonstrates that many courts, although employing disparate analyses, have implicitly embraced the cheapest cost avoider analysis.

\section{Analysis of Strict Liability Policies}

This part discusses the relative merits of the comparative apportionment and cheapest cost avoider approaches. ${ }^{13}$ The inquiry

and Negligent Parties, 20 S. TEx. L.J. 123 (1979). For an economic analysis of apportionment based on an assessment of causation, see Rizzo \& Arnold, Causal Apportionment in the Law of Torts: An Economic Theory, 80 CoLum. L. Rev. 1399 (1980).

When applied solely to allocation of damages among defendants, several commentators call the concept "comparative contribution." See Berg, Comparative Contribution and Its Alternatives: The Equitable Distribution of Accident Losses, 43 INs. Couns. J. 577 (1976); Davis, Comparative Negligence, Comparative Contribution and Equal Protection in the Trial and Settlement of Multiple Defendant Product Cases, 10 IND. L. REv. 831 (1977).

${ }^{11}$ See, e.g., City of Franklin v. Badger Ford Truck Sales, Inc., 58 Wis. 2d 641, 652-55, 207 N.W.2d 866, 871-73 (1973); see also V. SchWARTZ, supra note 7, at 46-52, 73-82.

${ }_{12}$ See Safeway Stores, Inc. v. Nest-Kart, 21 Cal. 3d 322, 335, 579 P.2d 441, 448, 146 Cal. Rptr. 550, 557 (1978) (Clark, J., concurring); see also Jensvold, A Modern Approach to Loss Allocation Among Tortfeasors in Products Liability Cases, 58 MinN. L. Rev. 723, 72425 (1974); St. Mary's Comment, supra note 10, at 607-09.

1s The analysis developed in this comment is concerned primarily with the long-run 
is organized by analyses of the four basic policies that underlie strict liability: deterring the entry of defective products into the marketplace, distributing the risk of loss as widely as possible, compensating injured consumers, and imposing the social costs of an enterprise on those who benefit directly from it.

\section{A. Deterrence}

Although deterring the entry of defective products into the marketplace is a fundamental goal of strict liability, ${ }^{14}$ courts and legislatures do not seek to prevent all possible defect-related accidents. Rather, tort law may be viewed as having the objective of optimal deterrence-that is, of deterring only those accidents whose costs to society ${ }^{15}$ exceed their prevention costs. ${ }^{16}$

effects of alternative liability approaches; several assumptions follow from this emphasis. Returning to the example in the introduction, it must be assumed that the defective steering system is not unique to $C$ 's car, but is a design defect that can be predicted to cause injury to other consumers. $A$ and $B$ therefore will be able to project accurately total accident costs due to the defective steering system. Second, $A$ and $B$ are assumed to know their own costs of prevention. Finally, the analysis presupposes that the market price of $A$ 's and $B$ 's products will adjust to reflect fully their accident and prevention costs.

This comment also sidesteps much of the debate over the definition of "defect" in the strict liability context. Although there is no standard definition, a common inquiry considers the appropriateness of a product's condition in light of its foreseeable uses. See Dickerson, Products Liability: How Good Does a Product Have to Be?, 42 IND. L.J. 301 (1967); Fischer, Products Liability-The Meaning of Defect, 39 Mo. L. Rev. 339 (1974); Keeton, Product Liability and the Meaning of Defect, 5 ST. Mary's L.J. 30 (1973); Montgomery \& Owen, Reflections on the Theory and Administration of Strict Tort Liability for Defective Products, 27 S.C.L. Rev. 803, 808-24 (1976); Phillips, The Standard for Determining Defectiveness in Products Liability, 46 U. CIN. L. REv. 101 (1977); Twerski, Rethinking, supra note 10, at 298-335; Vargo, Products Liability in Indiana-In Search of a Standard for Strict Liability in Tort, 10 IND. L. REv. 871, 871-88 (1977); Wade, On the Nature of Strict Tort Liability for Products, 44 Miss. L.J. 825, 828-38 (1973) [hereinafter cited as Products]; Wade, Strict Tort Liability of Manufacturers, 19 Sw. L.J. 5, $14-17$ (1965). Cf. Calabresi \& Hirschoff, Toward a Test for Strict Liability in Torts, 81 YALE L.J. 1055, 1060 (1972) (focusing on the parties' relative abilities to prevent the accident); Shapo, A Representational Theory of Consumer Protection: Doctrine, Function and Legal Liability for Product Disappointment, 60 VA. L. REv. 1109 (1974) (emphasizing product portrayal as a basis of liability).

14 See, e.g., Caterpillar Tractor Co. v. Beck, 593 P.2d 871, 877 (Alaska 1979); Escola v. Coca Cola Bottling Co., 24 Cal. 2d 453, 462, 150 P.2d 436, 440-41 (1944) (Traynor, J., concurring); MUPLA, supra note $9, \S 103(\mathrm{C})(3)$, reprinted in 44 Fed. Reg. 62,714, 62,720. But see Keeton, Products Liability-Some Observations About Allocation of Risks, 64 Mrch. L. Rev. 1329, 1333 (1966); Prosser, The Assault Upon the Citadel (Strict Liability to the Consumer), 69 YALE L.J. 1099 (1960).

16 "Accident costs," as used in this comment, include only such costs as could be compensated in a liability judgment against a manufacturer. Defective products may cause other costs to society that would not be so compensated. See G. Calabresi, The Costs or AcciDENTS 198-243 (1970). Elimination of these "externalities" would require a collective deci- 
1. Cheapest Cost Avoider Analysis. Professor Ronald Coase has demonstrated that, in the absence of transaction costs, market forces will ensure that optimal deterrence is achieved regardless of the initial legal allocation of accident costs. ${ }^{17}$ The Coase theorem implies that the burden of preventing a class of accidents eventually will be borne by the party who is able to prevent the accidents at least cost $^{18}$ - the cheapest cost avoider. ${ }^{19}$ Whenever accident costs exceed the cheapest cost avoider's prevention costs, those who bear the accident costs will bargain with the cheapest

sion to regulate, restrict, or ban the sale of products tending to create these costs. Such collective decisions, however, are outside the scope of a privately enforced system of tort law and thus outside the scope of this comment. See generally id. at 68-69; Calabresi, Does the Fault System Optimally Control Primary Accident Costs?, 33 LAw \& CoNTRMP. Probs. 429, 433 (1968).

Most jurisdictions do not allow recovery for purely economic or commercial loss, such as lost profits. See 1 Prod. LiAB. REP. II 4230 (CCH) (May 1981) (compiling cases). This reticence leaves real economic costs uncompensated, thus undermining one of strict liability's goals, optimal deterrence. An appropriate solution would be to allow recovery for all compensable damages; the doctrine could then be freed to work its intended result. A similar argument can be made for compensating emotional injury to the extent that it may be considered a social cost.

16 See Calabresi, The Decision for Accidents: An Approach to Nonfault Allocation of Costs, 78 Harv. L. Rev. 713, 716-21 (1965). See also Posner, A Theory of Negligence, $1 \mathrm{~J}$. Legal Stud. 29, 34 (1972). Optimal deterrence has been described as the minimization of the sum of accident costs and accident prevention costs. See Calabresi, Optimal Deterrence and Accidents, 84 YALE L.J. 656, 656 (1975); Chelius, Liability for Industrial Accidents: A Comparison of Negligence and Strict Liability Systems, 5 J. LEGAx Srud. 293, 294 (1976).

This discussion does not deny that considerations besides optimal resource allocation-such as justice, fairness, or morality-will be part of society's decision to deter accidents. See Fletcher, Fairness and Utility in Tort Theory, 85 HARv. L. Rev. 537 (1972); McKean, Products Liability: Trends and Implications, 38 U. CHr. L. Rev. 3 (1970). Cf. Epstein, A Theory of Strict Liability, 2 J. LegAL STUD. 151, 152 (1973) (criticizing economic analysts for failing to address questions of fairness). To the extent that these considerations are implicit in liability judgments, the definition of accident costs adopted will account for them. Indeed, the policies of compensation, enterprise liability, and risk spreading so clearly reflect these concerns that the doctrine of strict liability already represents most jurisdictions' chosen method for achieving justice, fairness, and morality in products liability cases.

Of course, some courts may feel that the doctrine does not always go far enough in this direction; morality, fairness, and justice may account for those cases in which punitive damages are awarded against a strictly liable defendant. See, e.g., Gryc v. Dayton-Hudson Corp., 297 N.W.2d 727, 732-33 (Minn.), cert. denied, 449 U.S. 921 (1980); Wussow v. Commercial Mechanisms, Inc., 97 Wis. 2d 136, 155-56, 293 N.W.2d 897, 907 (1980) ("While punitive damages have as one purpose the deterrence of similar future outrageous conduct, they also, as the very name suggests, are intended to punish . . . past willful, wanton, or reckless conduct."). See generally Owen, Problems in Assessing Punitive Damages Against Manufacturers of Defective Products, 49 U. CHI. L. Rev. 1 (1982); Owen, Punitive Damages in Products Liability Litigation, 74 Mrch. L. Rev. 1257 (1976).

${ }_{17}$ See Coase, The Problem of Social Cost, 3 J.L. \& Econ. 1 (1960).

18 Id. at 15.

10 See G. CarABresi, supra note 15, at 135. 
cost avoider to prevent the accident. The initial allocation of liability for defect-related accidents thus has no effect on the eventual allocation, because the parties will bargain until the cheapest cost avoider contracts to bear the liability. ${ }^{20}$

Sole reliance on the marketplace to achieve optimal deterrence, however, carries significant costs that often will justify judicial intervention and allocation of accident costs. Against the administrative costs of judicial intervention ${ }^{21}$ must be weighed at least two factors. First, private attempts to find the cheapest cost avoider usually involve transaction costs, ${ }^{22}$ and in many situations the costs of judicial intervention may be less than the sum of these private costs. ${ }^{23}$ Second, a cheapest cost avoider can be expected to charge a premium as part of its bargain to bear prevention costs. Depending on the parties' relative bargaining positions, this premium can range anywhere from just above zero to just below the difference between their prevention costs, resulting in a transfer of wealth. One could argue that cheapest cost avoiders should not profit by their ultimate responsibility, ${ }^{24}$ and that such transfers are unjust, even immoral.

When intervention is warranted, standards must be formu-

${ }^{20}$ See Calabresi, Transaction Costs, Resource Allocation and Liability Rules-A Comment, 11 J.L. \& Econ. 67 (1968); Chelius, supra note 16, at 294-95; Demsetz, When Does the Rule of Liability Matter?, 1 J. Legal Stud. 13, 14 (1972); Demsetz, The Exchange and Enforcement of Property Rights, 7 J.L. \& EcoN. 11 (1964).

${ }^{21}$ Administrative costs include the judicial costs of identifying the cheapest cost avoider and imposing liability on it. See generally Calabresi, supra note 15, at 439.

22 The total prevention costs therefore equal the lowest available prevention costs plus the sum of all transaction costs incurred. See G. CALABresI, supra note 15, at 136-38; Calabresi, supra note 15 , at $437-38$.

When transaction costs reach a prohibitive level, the Coase theorem no longer governs the transaction; the total accident prevention costs then equal the costs to the party who initially bears the liability. See G. CALABRESI, supra note 15, at 136-38; Calabresi, supra note 15, at 437-38. If the barriers to negotiation between partmakers and assemblers were this high, however, it seems that they would prevent most assemblers from even dealing with partmakers. The very existence of a final product assembled in multiple stages suggests that transaction costs are not prohibitive.

${ }^{23}$ In such cases, judicial intervention becomes desirable. See Calabresi, supra note 15, at 439 . One might argue that some partmakers and assemblers maintain such a close contractual relationship that they could costlessly shift the liability burden to the cheaper cost avoider. The California Supreme Court used this reasoning to support its assertion that "[s]trict liability on the manufacturer and retailer . . . works no injustice to the defendants ... ." Vandermark v. Ford Motor Co., 61 Cal. 2d 256, 262-63, 391 P.2d 168, 172, 37 Cal. Rptr. 896, 900 (1964). If this were the case, optimal deterrence would be achieved by a rule of no indemnity, no contribution, and no apportionment among such manufacturers.

${ }^{24}$ See generally Demsetz, Wealth Distribution and the Ownership of Rights, 1 J. LEGaL STUD. 223 (1972). 
lated for judicial allocation of accident costs. Both the maximization of deterrence and the minimization of its costs suggest that courts should replicate the private search for the cheapest cost avoider. ${ }^{25}$

a. Maximizing deterrence. A system that apportions liability based on relative degrees of culpability can discourage deterrence. For example, if partmaker $A$ has $\$ 20$ in prevention costs and assembler $B$ has $\$ 5$ in prevention costs, $B$ is the cheaper cost avoider. If a jury found $A$ to be $75 \%$ culpable for an accident and $B 25 \%$ culpable, and awarded $C \$ 10$ in damages, $A$ would pay $\$ 7.50$ and $B$ would pay $\$ 2.50$. As a result of this apportionment, however, neither $A$ nor $B$ would have an incentive to prevent future defects, for it would cost $A \$ 20$ to save $\$ 7.50$ in future liability and $B \$ 5$ to save $\$ 2.50$. Optimal deterrence is best promoted if the entire judgment is imposed on $B$, the cheaper cost avoider, because $B$ will then have an incentive to spend $\$ 5$ to save $\$ 10$ in future liability.

b. Minimizing costs. Even where the prevention costs of both the partmaker and the assembler are less than C's accident costs, thus guaranteeing deterrence however liability is allocated, the cheapest cost avoider should bear the full liability to achieve optimal deterrence. Thus, if $A$ has prevention costs of $\$ 20$ and $B$ of $\$ 5$, the cheapest and most efficient deterrence scheme will always make $B$ fully liable, for his prevention costs are $\$ 15$ less than $A$ 's.

2. Alternative and Joint Care. There are two components of cheapest cost avoider analysis. First, to prevent an accident, a party must become aware of and appreciate the risk of accident and the hazards it poses. ${ }^{26}$ The party must then be in a position to

2s Professors Calabresi and Hirschoff have suggested a test for strict liability that would impose liability on the party best able to analyze the costs and benefits of accident prevention and then "bribe" the cheapest cost avoider to bear liability. See Calabresi \& Hirschoff, supra note 13, at 1060-66. This suggestion implicitly assumes that the administrative costs of finding the cheapest analyzer-briber are lower than the transaction costs incurred by private attempts to do so, and that transaction costs incurred when the cheapest analyzerbriber bribes the cheapest cost avoider are lower than the administrative costs of additional judicial intervention. It seems, however, that whether an individual is best able to bribe the cheapest cost avoider necessarily depends on who the cheapest cost avoider is. Thus, in finding the cheapest briber, the court will also have found the cheapest cost avoider, and additional administrative costs will be close to zero. Thus if the first assumption were valid, complete intervention would be a more efficient solution than partial intervention. See also Posner, Strict Liability: A Comment, 2 J. Legal Stud. 205, 214-15 (1973).

${ }^{28}$ Note, 55 Minn. L. Rev. 1051, $1057-58$ (1971); cf. 2 L. Frumer \& M. Friedman, ProdUCTs LiABILITY § $16 \mathrm{~A}(5)(\mathrm{f})$, at 3B-218 (1977) (discussing requirements for defense of assumption of risk). 
control proximate events to prevent the risk from materializing. ${ }^{27}$ Once a consumer-plaintiff has demonstrated both the sale of a defective product and proximate cause, ${ }^{28}$ a court must determine which manufacturer faced the lowest costs of detection and control; that party will be the cheapest cost avoider.

The relative costs of two manufacturers may not always lend themselves to a straightforward cheapest cost avoider analysis. Naturally, where least-cost prevention can be achieved only if one manufacturer acts alone to prevent the defect, optimal deterrence requires imposing full liability on that manufacturer. This situation can be described as the "alternative-care case."29 There may be situations, however, in which least-cost prevention can be achieved only if both manufacturers take preventive measures. If,

${ }^{27}$ Cf. McKean, supra note 16, at 32 (illustrating the steps auto drivers and producers would have to take to prevent injuries from auto accidents).

28 There may be occasions when the consumer could have prevented the accident at a lower cost than either manufacturer. As an instrument of optimal deterrence, therefore, strict liability should be imposed only where the manufacturers had lower costs of prevention. This factor seems to be implicit in the "defective condition" and "proximate cause" requirements. Courts frequently note that manufacturers are not "absolute insurers," and a general public awareness of a product's danger or a consumer's superior knowledge of the product's intended use support findings of "no defect." See, e.g., Vincer v. Esther Williams All-Aluminum Swimming Pool Co., 69 Wis. 2d 326, 332, 230 N.W.2d 794, 798 (1975) ("If the average consumer would reasonably anticipate the dangerous condition of the product and fully appreciate the attendant risk of injury, it would not be unreasonably dangerous and defective."). Similarly, consumer misuse of a product often is held to constitute an intervening factor that negates proximate causation. See, e.g., Atkins v. American Motors Corp., 335 So. 2d 134, 143 (Ala. 1976); Illinois State Trust Co. v. Walker Mfg. Co., 73 Ill. App. 3d 585, 589-90, 392 N.E.2d 70, 73 (1979).

Even where a defect and proximate causation have been established, demonstration of a consumer's superior ability to prevent the accident can still bar recovery under the "assumption of risk" or "misuse" doctrines. Assumption of risk generally is pleaded as an affirmative defense and bars compensation to a plaintiff who "voluntarily and unreasonably proceed[ed] to encounter a known danger." RESTATEMENT (SECOND), supra note 1, § 402A comment n; see Epstein, Products Liability: Defenses Based on Plaintiff's Conduct, 1968 UTAH L. REV. 267, 270. "Misuse," on the other hand, generally refers to the use of a product for a purpose neither intended by nor foreseeable to the manufacturer. RESTATEMENT (SEcOND), supra, note 1, \&402A comment h; Epstein, supra, at 270. These doctrines rest on the premise that a consumer usually will face lower control costs than any manufacturer because he physically manipulates or places himself in proximity to the product. Accordingly, assumption of risk focuses on the consumer's ability to detect the danger and bars recovery when it appears that the consumer had detection costs that were lower than or comparable to the manufacturer's. Misuse, on the other hand, focuses on the manufacturer's ability to detect the danger and bars recovery when it appears that it could not have had lower detection costs than the consumer. Arguably, therefore, these doctrines enable courts and juries to conduct intuitive cheapest cost avoider inquiries.

29 See, e.g., Landes \& Posner, Joint and Multiple Tortfeasors: An Economic Analysis, 9 J. Legal Stud. 517, 526 (1980). 
for example, partmaker $A$ faces the lowest detection costs while assembler $B$ faces the lowest control costs, least-cost prevention requires that $A$ detect the defective condition and that $B$ correct it. For $A$ 's detection to be of any use to $B, A$ must inform $B$ of the defect. The total costs of joint prevention will be the sum of $A$ 's detection costs, $A$ 's warning costs, and $B$ 's control costs. When the sum of $A$ 's detection and warning costs are lower than $B$ 's detection costs, joint prevention will cost less than any other prevention method. This situation, which can be described as the "joint-care case," ${ }^{30}$ requires that specially tailored incentives be imposed on each manufacturer.

a. Duty to warn. Because detection of the defective or potentially defective condition must precede its correction, the most straightforward approach would be to impose full liability on the party with the lowest detection costs, but allow that liability to be shifted to the party with the lowest control costs upon a showing that the former effectively informed the latter of the condition. In the situation described above, $A$ would have a duty to warn $B$ of the defective condition, enforced by the threat of full liability; as long as the expected liability costs ${ }^{31}$ exceeded the sum of $A$ 's detection and warning costs, $A$ would have an incentive to detect the condition. After $A$ detected and warned $B$ of the condition, however, its duty would be discharged, and $B$ would then bear full liability. As long as expected liability costs exceeded $B$ 's control costs, $B$ would have an incentive to correct the condition. ${ }^{32}$

so Id. at 522 .

sI Expected liability costs are the amount of damages the manufacturer of a defective product would have to pay for resulting injuries, discounted by the probability that liability will be incurred. To achieve optimal deterrence, tort rules should be consistent so as to cause this probability to approach $100 \%$ in situations where the manufacturer should be liable, necessarily militating against the use of comparative liability as apportioned at the whim of a jury.

"2 Compare the approach taken in Mlinois, where the claimant-assembler and defendant-partmaker in an indemnity action are simply placed in the positions of an ordinary plaintiff and defendant. For the claimant to recover in strict liability, he must establish a plaintiff's prima facie case: that the product was defective when the defendant sold it, that the defect proximately caused the injury for which the claimant had been or might be held liable, and that the defect was "unreasonably dangerous." Liberty Mut. Ins. Co. v. Williams Mach. \& Tool Co., 62 Ill. 2d 77, 85, 338 N.E.2d 857, 861 (1975). The partmaker is entitled to the same defenses as an ordinary defendant, including the defense that the assembler assumed the risk that the injury would occur. Id. at 85, 338 N.E.2d at 860; McCaffrey v. Illinois Cent. Gulf R.R., 71 Ill. App. 3d 42, 49, 388 N.E.2d 1062, 1068 (1979). Assumption of risk, however, is not a complete defense to an action for contribution, because nllinois has adopted comparative contribution among defendants to avoid the "injustice" of a complete bar to third-party recovery. Skinner v. Reed-Prentice Div. of Package Mach. Co., 70 Ill. 2d 
Imposing liability for failure to warn of a defect or danger is a well-entrenched doctrine in strict liability; "defect" usually is defined in these cases as the absence or inadequacy of a warning. ${ }^{33}$ The duty-to-warn system would define $A$ 's failure to warn $B$ as a defect for which $A$ would bear full liability. ${ }^{34}$ Discharging the duty to warn would prevent the product from being "defective" as it left $A$ 's hands and thus would absolve $A$ of liability. Some cases, however, have implied that a defect exists regardless of the presence of an adequate warning. ${ }^{35}$ Under this view, $A$ 's warning would constitute an exculpatory act, relieving $A$ of liability for producing a defective product. ${ }^{36}$ Either way, a court would have little trouble applying this analysis once the costs of detection, warning, and control had been established.

In joint-care cases, the system proposed here will achieve optimal deterrence in all but one instance: where the costs of joint prevention are greater, and the minimum sum of detection and warn-

1, 374 N.E.2d 437 (1977), cert. denied, 436 U.S. 946 (1978). If traditional concepts of defect, proximate cause, misuse, and assumption of risk effectively cause accident cost burdens to fall on the cheapest cost avoider, see supra notes 16-19 and accompanying text, the Illinois approach to indemnity (absent its comparative contribution component) could prove highly useful in allocating liability among manufacturers. In the joint-care case, an assembler who had been warned effectively by the partmaker could be said to have assumed the risk and thus to be barred from recovery. Of course, this approach would be of little help when the partmaker sued the assembler for indemnity.

ss See, e.g., Union Supply Co. v. Pust, 196 Colo. 162, 173, 583 P.2d 276, 283 (1978); Berkebile v. Brantly Helicopter Corp., 462 Pa. 83, 100, 337 A.2d 893, 902 (1975); Teagle v. Fischer \& Porter Co., 89 Wash. 2d 149, 155, 570 P.2d 438, 442 (1977).

s4 It is important to note that under the duty-to-warn scheme developed here, the warning owed by $A$ to manufacturer $B$ may be completely different from the warning owed to consumer $C$. For example, if a component is innocuous by itself, but becomes dangerous when incorporated into a final assembly in a particular way, partmaker $A$ could have a duty to warn assembler $B$ not to so incorporate the part. See Thomas v. Kaiser Agricultural Chems., $81 \mathrm{ml}$. 2d 206, 217, 407 N.E.2d 32, $37-38$ (1980). Such a warning would be useless to a consumer because he would have no way of knowing, or perhaps even understanding, whether the part had been incorporated properly. The assembler who improperly incorporates the part, however, might incur a separate obligation to warn of the danger to the consumer thereby created. When "defect" is defined to encompass an inadequate warning, therefore, the defect in the product when the partmaker ships it need not necessarily be the same as the defect in the product when the assembler ships it. See Vandermark v. Ford Motor Co., 61 Cal. 2d 256, 260, 391 P.2d 168, 171, 37 Cal. Rptr. 896, 899 (1964); Sharp v. Chrysler Corp., 432 S.W.2d 131, 136 (Tex. Civ. App. 1968); Shawver v. Roberts Corp., 90 Wis. 2d 672, 685-86, 280 N.W.2d 226, 232-33 (1979); REstatEMENT (SEcoND), supra note 1, § $402 \mathrm{~A}$ comments $\mathrm{p} \& \mathrm{q}$.

ss See Sturm, Ruger \& Co. v. Day, 594 P.2d 38 (Alaska 1979), cert. denied, 102 S. Ct. 391 (1981).

${ }^{36}$ This could be done either by manipulating the definition of proximate cause or by holding that $B$ assumed the risk. See supra note 28 . 
ing costs are less, than the expected liability costs. ${ }^{37}$ If $A$ is the cheaper detector and warner at $\$ 23, B$ the cheaper controller at $\$ 25$, and the expected liability is $\$ 35, A$ and $B$ each will fulfill their duties to avoid liability, but the total costs of joint care will exceed by $\$ 13$ the expected liability. Moreover, control costs need not be less than expected liability for misallocation to occur. For example, if $A$ and $B$ faced the same costs as above, but expected liability was $\$ 24, A$ would spend $\$ 23$ to detect and warn while $B$ would pay $\$ 24$ for the accident rather than the $\$ 25$ necessary to prevent it. The result: a total social loss of $\$ 47$.

b. Comparative costs. To avoid these misallocations, a comparative cost system could be employed. This approach would seek to determine each party's costs of detection, warning, and control; to calculate the minimum joint cost of prevention; and to impose liability on each party in an amount equal to the full liability judgment, multiplied by the ratio of each party's minimum cost to the minimum joint prevention costs. Whenever total liability exceeded joint prevention costs, $A$ 's share of liability would exceed the sum of its detection and warning costs, and $B$ 's share of liability would exceed its control costs. Each party therefore would have an incentive to perform its role in preventing the defect. On the other hand, whenever total liability was less than the costs of joint prevention, $A$ 's share of liability would be less than the sum of its detection and warning costs, $B$ 's share would be less than its control costs, and neither party would try to prevent the accident. ${ }^{38}$

Despite its theoretical appeal, the comparative cost system has some serious practical drawbacks. First, the liability anticipated by one manufacturer necessarily depends on the precise costs faced by the other. Although it can be assumed that each party knows its own prevention costs, it may be unreasonable to assume that each knows the other's well, if at all. ${ }^{30}$ The duty-to-warn model requires

37 This case does not conflict with the argument that the no-contribution rule is always efficient in joint-care cases under a negligence system. See Landes \& Posner, supra note 29, at 522-26. Landes and Posner posited a negligence system where liability is imposed only where expected accident costs exceed prevention costs. Id. at 521. Under the strict liability system discussed here, liability is imposed even where expected accident costs fall below prevention costs.

38 Cf. Schwartz, Contributory and Comparative Negligence: A Reappraisal, 87 Yale L.J. 697, 705-06 n.44 (1978) (discussing similar methods of comparing the negligence of a plaintiff and a defendant in a negligence system).

s2 This could occur only if transaction costs involved in sharing cost information were relatively low. If this were the case, the Coase theorem would govern the transaction, and judicial intervention might be unnecessary. See supra notes 17-20 and accompanying text. 
firms to evaluate their relative costs, but it only calls for a crude approximation, not a precise dollar figure. Furthermore, conditioning one party's liability on the conduct of the other would create opportunities for extortion whenever the parties were in unequal bargaining positions or faced different levels of expected liability. ${ }^{40}$ The misallocations caused by these problems could exceed the misallocations of the duty-to-warn model.

Even if the comparative cost system created none of these misallocations, it would probably entail significantly higher administrative costs than the duty-to-warn model, for it requires the court to determine precise cost proportions, while the duty-to-warn model asks only who can more easily detect or correct the defect. The latter is a far more simple inquiry, one that juries are wellequipped to make. Moreover, to the extent that the courts' costs evaluations were inaccurate, their liability judgments would send flawed accident cost signals to manufacturers, thus resulting in suboptimal accident prevention. Assuming that both approaches are preferable to reliance on private market transactions, the choice depends on the relative danger of misallocations and the relative level of administrative costs. The duty-to-warn model appears to offer a clearer and less cumbersome method of apportionment. ${ }^{11}$

\section{B. Risk Spreading}

To minimize individual economic dislocations, ${ }^{42}$ manufacturers are held strictly liable on the theory that they can more easily insure against and distribute accident costs than individual victims. ${ }^{43}$ If a manufacturer bears liability for accidents caused by its

to See Demsetz, supra note 24 , at $230-32$.

41 The problem is reminiscent of the debate over the relative "efficiency" of negligence and strict liability. As Judge Posner has pointed out in that context, the issue "seems at this stage hopelessly conjectural; the question is at bottom empirical, and the empirical work has not been done." Posner, supra note 25, at 211-12.

42 See Feezer, Capacity to Bear Loss as a Factor in the Decision of Certain Types of Tort Cases, 78 U. PA. L. REv. 805, 809 (1930).

4s See Caterpillar Tractor Co. v. Beck, 593 P.2d 871, 877 (Alaska 1979); Price v. Shell Oil Co., 2 Cal. 3d 245, 251, 466 P.2d 722, 726, 85 Cal. Rptr. 178, 181-82 (1970) (en banc); James, Accident Liability Reconsidered: The Impact of Liability Insurance, 57 YaLB L.J., 549, 550 (1948); Noel, Manufacturers of Products-The Drift Toward Strict Liability, 24 TenN. L. REv. 963, 1010 (1957); Sachs, Negligence or Strict Product Liability: Is There Really a Difference in Law or Economics?, 8 GA. J. INT'L \& Comp. L. 259, 262 (1978); Wade, Products, supra note 13, at 826 . Whether this is true will depend on the realities of insurance availability and practice. When consumers carry insurance and are able to assess the 
defective products, it will insure against this risk either through self-insurance or by obtaining outside insurance. ${ }^{44}$

Imposing full liability on the "cheapest insurer" will achieve optimal risk spreading. Given consistent liability rules, an insurance company will charge no more in the long run to insure one manufacturer than another, as long as defective products cause consistent accident costs and all manufacturers face equal prevention costs. ${ }^{45}$ But when one manufacturer has lower prevention costs, the threat of liability will induce it to prevent more of the accidents, its actuarial risk of liability will be lower, and it will be able to obtain insurance at a lower cost. In other words, the search for the cheapest insurer simply recreates the search for the cheapest cost avoider. The conclusions drawn under optimal deterrence therefore apply as well to risk spreading, and both policies call for imposing liability on the same manufacturer. ${ }^{48}$

\section{Compensation and Enterprise Liability}

The policy of compensating injured consumers ${ }^{47}$ relates only tangentially to the apportionment problem, for the division of liability among tortfeasors does not affect the amount awarded to the victim. Where a tortfeasor is unable to satisfy its share of the judgment, however, the policy of full compensation requires that the

risk of injury, they may be "fully capable of assuming and distributing losses," and it might therefore be undesirable to shift losses from consumers to manufacturers. Keeton, supra note 14 , at 1334 .

4t See Posner, supra note 25, at 210. Some very large companies acquire, on their own or with other companies, insurance organizations that are known as captive insurers. See 1 U.S. Dep't of Commerce, Intrragency Task Force on Product Liabitity: Product LiabilITY, Final REPORT OF THE InsUrance Study 1-8 (1977) [hereinafter cited as Task Force REPORT]. Under recent federal legislation, moreover, groups of product manufacturers and sellers may pool their risk of product liability, thereby obtaining insurance that they might otherwise have been unable to afford or obtain. Product Liability Risk Retention Act, Pub. L. No. 97-45, 95 Stat. 949 (1981) (codified at 15 U.S.C.A. $\$ \$ 3901-3904$ (West Supp. 1982)).

${ }^{45}$ The recent upheavals in product liability rules have rendered liability losses highly unpredictable, thus accounting for much of the reluctance of insurance companies to insure certain product lines. See 1 TASK Force Report, supra note 44, at ES-5. This problem would be resolved in the long run by consistent liability standards.

40 Note that both policies might instead call for no judicial intervention, if the operation of the Coase theorem would impose liability on the appropriate manufacturer at a lower cost. See supra note 22.

4 See MUPLA, supra note $9, \S 103(\mathrm{c})(1)$, reprinted in 44 Fed. Reg. at 62,720. Traynor, The Ways and Meanings of Defective Products and Strict Liability, 32 TenN. L. Rav. 363, 376 (1965). But see Epstein, Products Liability: The Search for the Middle Ground, 56 N.C.L. REv. 643, 644-45 (1978). 
other tortfeasors make up the difference. ${ }^{48}$

Enterprise liability-the policy of imposing the social costs of an enterprise on those who benefit directly from $i^{49}$-also is unaffected by methods of allocating liability between partmakers and assemblers. ${ }^{\text {so }}$ Where a finished product can be manufactured in a single stage, its producers will pass a portion of their accident liability on to the product's consumers; the exact amount passed on depends upon the relative elasticities of supply and demand for the product. ${ }^{\text {sI }}$ In situations where multiple producers combine to manufacture a finished product, the method of apportioning liability among producers may affect the proportion of liability costs that can be passed on to the product's consumers. ${ }^{62}$ Whether liabil-

18 See MUPLA, supra note 9, § 111(B)(6), reprinted in 44 Fed. Reg. at 62,735; W. Prosser, HaNdBook of THe LAw OP TorTs $\$ 100$, at 662-65 (4th ed. 1971).

19 See Santor v. A \& M Karagheusian, Inc., 44 N.J. 52, 65, 207 A.2d 305, $311-12$ (1965); Goldberg v. Kollsman Instrument Corp., 12 N.Y.2d 432, 440, 191 N.E.2d 81, 85, 240 N.Y.S.2d 592, 598 (1963) (Burke, J., dissenting); James, General Products-Should Manufacturers Be Liable Without Negligence?, 24 TENN. L. REv. 923, 926-27 (1957).

In a sense, both enterprise liability and risk spreading may be viewed simply as two stages in the process by which an activity's social costs are imposed on its beneficiaries. As Professor Calabresi has noted, most definitions of enterprise liability refer to some form of risk spreading. G. CALABRESI, supra note 15, at 50-54. Calabresi has characterized one function of enterprise liability as achieving an optimal allocation of resources. By causing a product's accident costs to be reflected in its price, consumers can determine more accurately whether its benefits outweigh its costs. See Calabresi, Some Thoughts on Risk Distribution and the Law of Torts, 70 YALE L.J. 499, 500-03 (1961). Viewed in this way, risk spreading is an incidental consequence of enterprise liability. Id. at 501. The goal of risk spreading in minimizing individual economic dislocations carries independent force, however. See Feezer, supra note 42 , at 809 . For this reason, the two policies are treated separately in this comment.

so As used in this context, "enterprise liability" should not be confused with those doctrines that visit the sins of one manufacturer upon an entire industry. See, e.g., Hall v. E.I. du Pont de Nemours \& Co., 345 F. Supp. 353, 380 (E.D.N.Y. 1972) (once duty of care established, each member of blasting cap industry had burden of proving its products did not cause the accident); Sindell v. Abbott Labs., 26 Cal. 3d 588, 607 P.2d 924, 163 Cal. Rptr. 132 (1980) (liability for all DES industry members with a substantial portion of the market, in proportion to their relative market shares), cert. denied, 449 U.S. 912 (1980); Abel v. Eli Lilly \& Co., 94 Mich. App. 59, 289 N.W.2d 20 (1979) (all known manufacturers of DES whose products were distributed in Michigan at the relevant time held jointly and severally liable for personal injuries suffered by plaintiffs). In this comment, "enterprise" refers solely to the manufacturer or manufacturers proven to have produced the defective product that caused the injury.

s1 See Calabresi, supra note 49 , at 519-27. In a competitive environment, a producer whose products have a defect that is not common to its competitor's products will be unable to pass any liability on to consumers and will be forced to bear all liability that results from accidents caused by the defect. If such a producer attempted to pass on a portion of its liability costs through higher prices charged to consumers, they would quickly begin purchasing a competitor's products instead.

${ }^{32}$ As long as transaction costs are not prohibitive, multiple producers will bargain 
ity is fastened on one producer or apportioned among them, however, the goals of enterprise liability will not be undermined: the product's accident costs will continue to be distributed only among its manufacturers and consumers.

\section{LEgAL IMPLicAtions}

The cheapest cost avoider analysis developed in part I illustrates the inherent flaws of comparative apportionment between component manufacturers and assemblers in strict liability cases. In City of Franklin v. Badger Ford Truck Sales, Inc. ${ }^{53}$ for example, the Wisconsin Supreme Court denied a chassis assembler and a chassis dealer indemnity against a wheel manufacturer for a defective wheel that caused a city fire truck to overturn. Although the manufacturer "had exclusive control of the design, material, selection, chemistry, and workmanship of the wheel,",54 and although there was no way to inspect the wheel for the defect "except by removing a core sample which would render [it] unusable,""ss the court remanded the case so that the jury could assess percentages of comparative liability among the manufacturer, assembler, and dealer. ${ }^{56}$ The court all but stated that the manufacturer had the lowest costs of detection and control, yet it sent the case back for a hopelessly arbitrary liability allocation. Granting full indemnity against the manufacturer would have best served the policies of strict liability. ${ }^{57}$

among themselves to impose their liability burden on the cheapest cost avoider, thereby incurring transaction costs. See supra notes $22-25$ and accompanying text. Supply elasticity will therefore increase in response to economies of scale (and decrease in response to diseconomies of scale) in such Coase theorem transactions.

Where an individual manufacturer makes products with defects not common to its competitor's products, it will be unable to shift liability costs forward or back onto other producers or suppliers. For example, if partmaker $A$ is held liable, assemblers like $B$ will refuse to compensate him for his increased costs, for they can acquire components elsewhere at the original market price. If liability for a defective component is instead imposed on $B$, he will quickly discover that his marginal costs can be reduced by converting to nondefective components. Similar forces will prevent a defective assembler from shifting its liability burden back onto its component suppliers.

ss 58 Wis. $2 \mathrm{~d} 641,207$ N.W.2d 866 (1973).

s4 Id. at 645,207 N.W.2d at 867.

${ }^{3 s} I d ., 207$ N.W.2d at 868.

Bs Id. at 654-55, 207 N.W.2d at 872-73. The lower court had granted indemnity to the chassis dealer against the assembler, but had denied indemnity to the assembler against the manufacturer. The supreme court reversed both decisions.

${ }^{87}$ Although this comment focuses solely on apportionment between partmakers and assemblers, the cheapest cost avoider analysis can also be applied to distributors, dealers, and retailers to govern their relative liabilities. For example, Alabama provides a complete 
The outcomes of other cases, however, seem consistent with cheapest cost avoider analysis. Burbage $v$. Boiler Engineering and Supply Co. ${ }^{58}$ is illustrative. In that case, the Pennsylvania Supreme Court granted full indemnity to the assembler against the manufacturer of a defective boiler valve, stating that "there is no reason why [the assembler] should have discovered the defect." Put into cheapest cost avoider terms, the court's reasoning indicates that the assembler faced higher detection costs than the partmaker. If, as appears likely, the assembler also faced higher control costs, then granting full indemnity against the valve manufacturer was the proper outcome. ${ }^{60}$

Intuitive renditions of the cheapest cost avoider test are frequently used in cases where the defect arose from the absence of a safety device. Schipper $v$. Levitt \& Sons, Inc. ${ }^{61}$ for example, which nicely illustrates the duty-to-warn paradigm, involved an assembler who had installed the partmaker's heating units into a complete boiler system without including necessary mixing valves. Absolving the partmaker of liability for the resulting injuries, the New Jersey Supreme Court found that it would have been impractical for the partmaker to install mixing valves at its stage of production, ${ }^{62}$ that the assembler had "deliberately disregarded" a strong recommendation by the partmaker to use mixing valves, ${ }^{63}$ and that the assembler was "highly responsible," with "extensive experience in the field." The court concluded that because the partmaker could not compel the assembler to purchase and install mixing valves, "no just purpose would be served by affixing respon-

\footnotetext{
"causal relation" defense against strict liability for distributors and packagers of finished products if they can show that the product was received in the defective condition, that they did not contribute to that condition, that they were unaware of it, and that they had no opportunity to inspect the product. See Atkins v. American Motors Corp., 335 So. 2d 134, 143 (Ala. 1976). Satisfaction of these four requirements proves that the distributor or packager had higher detection and control costs than the manufacturer. Unfortunately, the causal relation defense is unavailable to product manufacturers where the defect is in a component made by a third party. $I d$.

ss 433 Pa. 319, 249 A.2d 563 (1969).

so Id. at 326,249 A.2d at 567 . The boiler valve had an indentation on its face that caused the boiler to explode. The factfinder determined that the valve was in this condition when it left the component manufacturer. Id. at 325, 249 A.2d at 566.

so See also Herman v. General Irrigation Co., 247 N.W.2d 472, 478 (N.D. 1976) (holding manufacturer of defective engine liable in indemnity to the assembler-seller of irrigation system).

1244 N.J. 70, 207 A.2d 314 (1965).

${ }^{62}$ Id. at 98,207 A.2d at 330 .

es Id. at 97, 207 A.2d at 329 .

at Id. at 98, 207 A.2d at 329 .
} 
sibility to it in addition to [the assembler]. ${ }^{985}$ Put in cheapest cost avoider terms, the partmaker's warning shifted liability to the assembler, who had lower control costs. ${ }^{66}$

Similar inquiries are sometimes made where the assembler is also the ultimate consumer of the final product. In Shawver $v$. Roberts Corp. ${ }^{67}$ for example, the Wisconsin Supreme Court absolved the partmaker of liability where the assembler-consumer included the partmaker's components in a conveyor belt assembly without adequate safety devices in the electrical control system. It was "not feasible or practical" for the partmaker to include safety devices at its stage of production, because such devices had to be "integrated with a control system and the general work environment." "68 Moreover, the partmaker had no duty to warn the assembler, because the latter had its own engineering department that routinely evaluated and incorporated safety devices in products it assembled. ${ }^{69}$ Put another way, the assembler certainly had lower control costs and probably lower detection costs as well. ${ }^{70}$

Id. at 99, 207 A.2d at 330 .

* See also Willeford v. Mayrath, $7 \mathrm{Ml}$. App. 3d 357, 361, 287 N.E.2d 502, 505 (1972) (partmaker not liable for assembler's failure to install a safety shield in an elevator where assembler "knew of the importance of attaching the shield" and the partmaker had "no control" over the assembly process); State Stove Mfg. Co. v. Hodges, 189 So. 2d 113, 122 (Miss. 1966) (partmaker not liable for installer's failure to include a safety valve where partmaker explicitly instructed installer on the installation of the valve and where the valve was "customarily" and "more conveniently" installed by the installer), cert. denied, 386 U.S. 912 (1967). But see DeSantis v. Parker Feeders, Inc., 547 F.2d 357, 361 (7th Cir. 1976) (partmaker held fully liable for assembler's failure to install safety guard where guard could have been attached when product was in partmaker's hands).

1790 Wis. 2d 672, 280 N.W.2d 226 (1979).

es Id. at $685-86,280$ N.W.2d at 233. The court found that the defect arose from the nature and location of the controls and that the partmaker had shipped the conveyor system unassembled and without controls.

-9 Id. at 686,280 N.W.2d at 233.

${ }^{70}$ See also Taylor v. Paul O. Abbe, Inc., 516 F.2d 145, 148 (3d Cir. 1975) (applying Pennsylvania law) (gear manufacturer absolved of liability for injury to assembler's employee where assembler failed to include safety guard after refusing manufacturer's offer to sell such a guard). The court in Taylor drew a fine line between a partmaker that sells an incomplete product for final assembly by the purchaser and the manufacturer that sells a complete product lacking a safety device. Id. at 148-49. See, e.g., Bexiga v. Havir Mfg. Corp., 60 N.J. 402, 410, 290 A.2d 281, 285 (1972) (product is defective if manufacturer could feasibly include the safety device, even though manufacturer could have foreseen that the purchaser would not install it); Temple v. Wean United, Inc., 50 Ohio St. 2d 317, 364 N.E.2d 267 (1977) (partmaker not liable where assembler modified punch press so as to render the press unsafe without a safety guard). In Temple, the court held that the duty to warn "does not extend to the speculative anticipation of how manufactured components, not in and of themselves dangerous or defective, can become potentially dangerous dependent upon the nature of their integration into a unit designed and assembled by another." Id. at 324, 364 
Detection issues sometimes arise where a partmaker manufactures components according to an assembler's specifications. In Moon v. Winger Boss Co., ${ }^{71}$ a conveyor that lacked safety devices when it left the partmaker's hands caused injury to the assembler's employee. The conveyor, however, was designed by the assembler as part of an overall plant design, and the assembler refused to show the partmaker the plant design or give it access to the plant. ${ }^{72}$ The Nebraska Supreme Court upheld the lower court's summary judgment for the partmaker, reasoning that the partmaker could not be expected to add safety devices without a knowledge of the environment in which the conveyor would be used. ${ }^{73}$ In other words, the assembler's secrecy made the partmaker's detection costs prohibitive.

In Verge v. Ford Motor Co., ${ }^{74}$ the Third Circuit went beyond intuitive use of the cheapest cost avoider test. The defect involved was the lack of a warning buzzer on a garbage truck, which would sound when the truck was put in reverse. The partmaker manufactured the truck's cab and chassis, and the assembler converted the chassis into a garbage truck. The court held that liability as between the two should be decided by trade custom, relative expertise, and practicality. ${ }^{75}$ The court could not examine trade custom for lack of evidence, ${ }^{76}$ but held that the evidence on the other two factors suggested that the assembler should be fully liable. It was not "feasible" for the partmaker to determine which units would be converted into garbage trucks and would therefore require warning buzzers, ${ }^{77}$ and the assembler had greater expertise in and total control over the process of assembling garbage trucks. ${ }^{78}$

Viewed in light of the cheapest cost avoider test, trade custom might have provided evidence of relative costs by showing how the

N.E.2d at 272 . The assembler, moreover, had known for years that using such guards would prevent the accident in question, so that it would be "[m]anifestly . . . futile to require that [the partmaker] notify [the plaintiff] of that which the responsible party [the assembler] . . was already aware." Id. at 325,364 N.E.2d at 272 . Even though the court did not explicitly say so, it effectively held that a partmaker has no duty to warn an assembler of a danger when the assembler has lower control costs and lower or equal costs of detecting the danger.

${ }^{71} 205$ Neb. 292, 287 N.W.2d 430 (1980).

72 Id. at 300,287 N.W.2d at 434.

7s Id. at $299-300,287$ N.W.2d at 434.

34 581 F.2d 384 (3d Cir. 1978).

75 Id. at 387 .

${ }^{76} \mathrm{Id}$. at $387-88$.

77 Id. at 387,389 .

78 Id. at 388 . 
market has allocated the duty to install safety devices. ${ }^{7 \theta}$ The partmaker did not have the lowest detection costs, for only the assembler could practically determine which units would become garbage trucks. Expertise accounts for both detection and control costs, for the assembler chose the units for conversion and had exclusive control over the conversion process.

Verge and its progeny ${ }^{80}$ reflect a welcome trend in tort law, indicating that courts are striving to formulate workable criteria to impose appropriate incentives on potential tortfeasors. Much confusion can be avoided if in each case courts ask, first which party is better able to learn of the potentially hazardous condition, and second, which is better able to control the production process to prevent such hazards from materializing.

\section{Conclusion}

Analysis of the major policies behind strict products liability demonstrates that objective standards must guide the apportionment of liability between partmakers and assemblers; schemes of comparative apportionment yield satisfactory results only through pure chance. Where judicial intervention is necessary, courts should structure liability to create incentives for parties to prevent defects at the least cost. This comment has argued that this goal is best achieved by determining the parties' relative costs of detection and control. In the alternative-care case, full liability should be placed on the cheapest cost avoider. In the joint-care case, a duty to warn should be imposed on the cheapest detector, satisfaction of which would shift full liability to the cheapest controller. Consistent, reasoned application of this approach will most effectively achieve the goals underlying strict liability.

Richard D. Cunningham

70 The court's decision to proceed with a resolution despite the absence of evidence of trade custom, id. at $387-88$, implies that it viewed this element as relatively unimportant. In any event, trade custom should be rebuttable by more direct evidence of relative costs.

so See Mayberry v. Akron Rubber Mach. Corp., 483 F. Supp. 407, 413 (N.D. Okla. 1979) (component manufacturer not responsible for "the ultimate design and construction of . . . the safety devices"); Mott v. Callahan AMS Mach. Co., 174 N.J. Super. 202, 210, 416 A.2d 57, 61 (Super. Ct. App. Div. 1980) (remanding for plenary trial to apply the three-pronged Verge test). See also Elliott v. Century Chevrolet Co., 597 S.W.2d 563 (Tex. Civ. App. 1980) (manufacturer and original seller of beer truck chassis absolved of liability in a negligence action on facts almost identical to those in Verge). 